\title{
Triticale (X. Triticosecale Witt.) hay as supplement for grazing cows in small-scale dairy systems in the highlands of central Mexico
}

\author{
M.N. Marín-Santana ${ }^{1}$, E. Torres-Lemus ${ }^{1}$, F. López-González ${ }^{1}$, E. \\ Morales-Almaraz ${ }^{2}$ and C.M. Arriaga-Jordán ${ }^{1 *}$
}

\author{
${ }^{1}$ Instituto de Ciencias Agropecuarias y Rurales (ICAR) and ${ }^{2}$ Facultad de Medicina Veterinaria y \\ Zootecnia, Universidad Autónoma del Estado de México (UAEM), Campus El Cerrillo, El Cerrillo \\ Piedras Blancas, C.P. 50090, Toluca, Estado de México, México \\ *Corresponding Author e-mail: cmarriagaj@uaemex.mx
}

Journal of Livestock Science (ISSN online 2277-6214) 12: 206-212

Received on 8/5/21, Accepted on 12/6/21, Published on 10/7/21

doi.10.33259/JLivestSci.2021.206-212

\begin{abstract}
Small-scale dairy systems ameliorate poverty and contribute to rural development. The dry season generates feed scarcity, and farmers must develop strategies based on quality forage to reduce purchased inputs. The objective was to assess the performance of dairy cows grazing perennial ryegrass or tall fescue pastures both associated with white clover complemented with triticale (X. Triticosecale Witt.) hay during the dry season, as well as the agronomic and chemical composition of pastures and complements. An on-farm experiment was undertaken with a $4 \times 4$ Latin Square design with a factorial arrangement, using four Holstein cows. Treatments were TFH= Tall fescue with white clover $+3.0 \mathrm{~kg}$ dry matter(DM)/cow/day of triticale hay, $\mathrm{RGH}=$ Perennial ryegrass with white clover $+3 \mathrm{~kg} \mathrm{DM} / \mathrm{cow} / \mathrm{day}$ of triticale hay, $\mathrm{RGNH}=$ Perennial ryegrass with white clover (no hay), and $\mathrm{TFNH}=$ Tall fescue with white clover (no hay). Grazing was for $8 \mathrm{~h}$ /day in two pastures (ryegrass and tall fescue) of 0.83 ha each, and cows received $4.45 \mathrm{~kg}$ DM of concentrate/cow/day. There were no significant differences $(\mathrm{P}>0.05)$ in sward height or net herbage accumulation. Contents of dry matter, crude protein, NDF and ADF, as well as the digestibility of organic matter and metabolizable energy were similar between pastures $(\mathrm{P}>0.05)$. There were no differences $(\mathrm{P}>0.05)$ among treatments for any productive performance variables, but there were statistical differences for estimated herbage intake $(\mathrm{P}<0.05)$. Conclusion was that complementing $3.0 \mathrm{~kg} \mathrm{DM}$ of triticale hay/cow/day did not show any significant effect on any of the evaluated variables but could reduce grazing pressure in pastures.
\end{abstract}

Keywords: Feeding strategies; alternative forages; Triticale hay; grazing, small scale dairy system; Mexico, 


\section{Introduction}

Small-scale dairy systems (SSDS) are considered worldwide as a viable option for rural development and for ameliorating poverty of farming families and their communities(Mc Dermott et al., 2010), as is the case in the central highlands of Mexico (Espinoza-Ortega et al., 2007). SSDS are defined by farms with small land holdings, herds between 3 and 35 cows plus replacements, and who rely on family labour for the operation of their farms (Fadul-Pacheco et al., 2013). Milk sales are the main source of income that may be complemented with off-farm work (Espinoza-Ortega et al., 2007).

Feeding strategies in farms with access to some irrigation in the highlands of central Mexico are based on cut and carry pastures of temperate grasses (mainly perennial ryegrass and tall fescue) and legumes (white clover predominantly), complemented with concentrates and conserved forages, mainly straws (Martínez-García et al., 2015).

Grazing of pastures instead of cut and carry herbage reduces feeding costs and improves the profitability of farms (Prospero-Bernal et al., 2017). However, due to restricted irrigation, growth decreases drastically in pastures of both species and there is a need for complementary forages during the dry season (Albarrán et al., 2012; Sainz-Ramírez et al., 2021). Farmers have traditionally supplied maize stover and other cereal straws (like oats, barley, and wheat) as complements during the dry season, and maize silage has proven a useful conserved forage for the dry season reducing feeding costs (ProsperoBernal et al., 2017), such that $30 \%$ of farmers have implemented maize silage in the feeding strategies for their herds in the dry season (Martínez-García et al., 2015). However, maize has a long growth cycle, requires uniform rainfall, and weather conditions in late summer early autumn make it difficult to ensile at the optimal stage (Anaya-Ortega et al., 2009).

Silage of small-grain cereals has been successfully evaluated as an option to provide quality conserved forage in the dry season for dairy cows in these systems (Gómez-Miranda et al., 2020), and these studies have included triticale (X. Triticosecale Witt.) silage as an option (González-Alcántara et al., 2020). However, ensiling is a complex process that requires expertise and the machinery to ensile smallgrain forage is not always easily available in farming communities being difficult to contract by the smaller farmers.

Hay is the oldest way of conserving forage (Suttie, 2000) and hay is still very important in the feeding strategies of livestock both in developed (Haselmann et al., 2020; Serrapica et al., 2020), as in developing countries both in large scale operations (Santana et al., 2020) as in small-scale livestock systems like in the north-eastern hills of India (Feroze et al., 2017). Suttie (2000) in the book published by FAO states that hay "can be made with simple equipment, manually or with mechanization, and many small-scale farming systems make hay to assure livestock feed through the lean season". Therefore, conserving forage as hay may be an option for small-scale dairy systems as it can be made manually, or given the long-standing tradition of straw bales, mechanical balers are readily available for small-scale farmers to contract in farming communities in the central highlands of Mexico. Triticale (X. Triticosecale Witt.), a hardy intergeneric hybrid between wheat (Triticum aestivum) and rye (Secale cereale), is an attractive forage alternative given its high yield and low water requirement particularly important for situations where rainfall may be erratic (Sánchez-Gutiérrez and Gutiérrez-Bañuelos, 2015).

The objective was to assess the performance of dairy cows grazing perennial ryegrass or tall fescue pastures both associated with white clover complemented with triticale hay during the dry season, as well as the agronomic and chemical composition of pastures and complements.

\section{Materials and methods Study area}

The study followed a participatory livestock technology development approach (Conroy, 2005) through an on-farm experiment with a collaborating farmer in the municipality of Aculco in the highlands of central Mexico, located between coordinates $20^{\circ} 06^{\prime}$ and $20^{\circ} 17^{\prime} \mathrm{N}$ and at $99^{\circ} 40^{\prime}$ and $100^{\circ} 00^{\prime} \mathrm{W}$, and a mean altitude of $2440 \mathrm{~m}$; with a sub-humid temperate climate, and a mean temperature of $13.2^{\circ} \mathrm{C}$ with frosts in winter. Annual rainfall is between 800 and $1000 \mathrm{~mm}$ with rains in summer between May and October, and a dry season from November to April (Valle-Aguilar et al., 2020).

\section{Animals and treatments}

Four multiparous lactating Holstein cows were used in the experiment. Cows were milked by hand twice daily, at 7:00 and 16:00 feeding was in a mixed system, with day grazing for $8 \mathrm{~h} / \mathrm{day}$, and overnight confinement in a tie-stall.

Cows grazed from 8:00 to 16:00 $\mathrm{h}$ two 0.83 ha pastures each, one sown to perennial ryegrass (Lolium perennecv. Bargala), and the other to tall fescue (Lolium arundinaceum, previouslyFestuca arundinaceacv K31), both pastures were associated with white clover (Trifolium repens cv. Ladino). 
Drinking water was freely available at pasture. Fertilisation of pastures was with $66 \mathrm{~kg} \mathrm{~N} / \mathrm{ha}$ and $23 \mathrm{~kg}$ $\mathrm{P}_{2} \mathrm{O}_{5}$ /ha before the experiment, using urea and diamonnium phosphate, and 30 days afterwards with $23 \mathrm{~kg}$ $\mathrm{N} / \mathrm{ha}$ as urea.

Cows were each supplemented with $4.45 \mathrm{~kg}$ dry matter (DM) of commercial dairy compound concentrate (with $18 \% \mathrm{CP}$ ) per day divided in two meals, each provided during the morning and evening milkings. Cows on hay treatments received individually $3.0 \mathrm{~kg}$ triticale hay/cow/day, also divided in two allocations of $1.5 \mathrm{~kg} \mathrm{DM}$ after each milking. The participating farmer insisted on the amount of concentrate provided based on their traditional feeding practices, in the belief that dairy cows need large amounts of concentrate to produce milk. Given the participatory nature of the experiment, his decision was respected.

The experiment was a 4x4 Latin Square design with a factorial arrangement, with four dairy cows from the collaborating farmer's small herd. Cows were similar in parity, days in milk and milk yields prior to the commencement of the experiment. Treatments were TFH= Tall fescue with white clover $+3.0 \mathrm{~kg} \mathrm{DM} / \mathrm{cow} /$ day of triticale hay, $\mathrm{RGH}=$ Perennial ryegrass with white clover $+3 \mathrm{~kg}$ $\mathrm{DM} /$ cow/day of triticale hay, RGNH= Perennial ryegrass with white clover (no hay), and TFNH= Tall fescue with white clover (no hay), to enable comparing the two pastures based on different grass species, the effect of the hay complement, and possible interactions between pasture type and hay complement. There were four experimental periods of 14 days duration each, ten days for adaptation to diets and the last 4 days of each experimental period for sampling. Cross-over designs like Latin Squares with short periods are well established in studies on feeding strategies for dairy cows (Miguel et al., 2014; PlataReyes et al., 2018; Sainz-Ramírez et al. 2021). Mean daily milk yield was used for analyses.

Milk yield was recorded at each milking for the four days, taking milk samples and a composite aliquot sample was formed $(50 \mathrm{~mL})$ and kept at $-20{ }^{\circ} \mathrm{C}$ till analyses.Milk fat, protein and lactose content were determined with an ultrasound milk analyser (Lacticheck model LC/01). Milk urea nitrogen (MUN), as an indicator of protein nutrition, was determined with the enzymatic colorimetric method of Chaney and Marbach (1962). Live weight of cows was recorded at the end of each experimental period when body condition score on a 1 to 5 scale was also recorded(Plata-Reyes et al., 2018).

Herbage dry matter intake (HDMI) from pastures was estimated from metabolizable energy (ME) requirements (AFRC, 1993) and the estimated ME content of herbage, triticale hay and concentrate from IVOMD, subtracting ME intake in concentrate and triticale hay from total ME requirements to obtain estimated HDMI following Celis-Alvarez et al. (2016). Sward height of pastures was recorded at the end of each experimental period taking 20 recordings per pasture with a rising plate grass meter following a zig-zag pattern (Plata-Reyes et al., 2018). Net herbage accumulation (NHA) of pastures was estimated from three $0.5 \times 0.5 \times 0.8 \mathrm{~m}$ grazing exclusion cages per pasture from differences between herbage mass on day 14 inside the cages minus the herbage mass on day 1 outside the cages and expressed as $\mathrm{kg}$ DM/ha per period and per day following Plata-Reyes et al. (2018).

\section{Chemical analyses}

Chemical analyses of feeds followed standard procedures described by Anaya-Ortega et al. (2009). Analyses were for dry matter (DM), organic matter (OM) from ash content, crude protein (CP) and neutral detergent fibre (NDF) and acid detergent fibre (ADF). Enzymatic in vitro organic matter digestibility (IVOMD) followed Riveros and Argamentaría (1987); and estimated metabolizable energy (ME) was determined fromAFRC (1993).

All chemical analyses were performed at the laboratory of the Institute of Agricultural and Rural Sciences of the Autonomous University of the State of Mexico (Instituto de Ciencias Agropecuarias y Rurales, Universidad Autónoma del Estado de México) located in the municipality of Toluca in the State of Mexico.

\section{Experimental design}

Mean sward height and net herbage accumulation (NHA) as pasture variables were analysed with ANOVA in a split-plot design where pasture type (perennial ryegrass or tall fescue) were fixed effects (main plots), and the four experimental periods were random effects (split plots), with the following model(Kaps and Lamberson, 2004):

$\mathrm{Y}_{\mathrm{ijkl}}=\mu+\mathrm{r}_{\mathrm{i}}+\mathrm{T}_{\mathrm{j}}+\mathrm{E}_{\mathrm{k}}+\mathrm{p}_{\mathrm{l}}+\mathrm{Tp}_{\mathrm{jl}}+\mathrm{e}_{\mathrm{ijk}}$

Where: $\mu=$ General mean; $r=$ Effect of replicates $(i=3$ for NHA); $\mathrm{T}=$ Effect of pasture type (Main Plot) $(\mathrm{j}=1,2) ; \mathrm{E}=$ Error term for Main Plots $[\mathrm{r}(\mathrm{T}) \mathrm{ij}] ; \mathrm{p}=$ Effect of experimental periods (split $-\mathrm{plot})(\mathrm{k}=1$, ..., 4); Tp = Interaction term between treatments (pasture type) and measurement periods; e = Error term. Animal variables were analysed via ANOVA with a 4 x 4 Latin Square with a 2 x 2 factorial arrangement (Kaps and Lamberson, 2004). Factors were the grass species in pastures (perennial ryegrass vs. tall fescue), and the second factor was triticale hay complementation (with or without hay). 
The statistical model was:

$\mathrm{Y}_{\mathrm{ijkl}}=\mu+\mathrm{C}_{\mathrm{i}}+\mathrm{P}_{\mathrm{j}}+\mathrm{G}_{\mathrm{k}}+\mathrm{H}_{\mathrm{l}}+\mathrm{G}^{*} \mathrm{H}_{\mathrm{m}}+e_{\mathrm{ijklm}}$

Where: $\mu=$ General mean, $\mathrm{C}=$ Effect due to $\operatorname{cows}(\mathrm{i}=1,2,3,4) ; \mathrm{P}=$ Effect due to experimental periods $(\mathrm{j}$ $=1,2,3,4) ; \mathrm{G}=$ Effect due to grass species in pastures $(\mathrm{k}=1,2), \mathrm{H}=$ Effect due to hay inclusion $(\mathrm{l}=1,2)$; $\mathrm{G}^{*} \mathrm{H}=$ Effect due to the interaction between grass species and hay inclusion; $e=$ Error term.

Cross-over designs as Latin Squares are useful for on-farm experiments with smallholders, as they maximise limited experimental units (cows) (Kaps and Lamberson, 2004); and have been successful in research with a limited number of cows and short experimental periods previously reported by Miguel et al. (2014) from work in Brasil,and Granados-Rivera et al. (2017) from work on tropical dairy production.

This paper reports an on-farm experiment undertaken with a participating farmer who had knowledge of the objectives of the work, was duly informed at all times, and actively participated in planning and undertaking the experiment. His privacy is respected by not disclosing his name. The experiment with dairy cows and collaborating farmers followed accepted procedures by Universidad Autónoma del Estado de México.

Authors declare there is no conflict of interests.

\section{Results}

\section{Pasture variables}

Table 1 shows results for sward heights $(\mathrm{cm})$ and net herbage accumulation by period for each pasture. There were no differences $(\mathrm{P}>0.05)$ in sward height or herbage accumulation between pastures.Being the dry season, NHA was limited to $43 \mathrm{~kg} \mathrm{DM} / \mathrm{ha} /$ day which represented a herbage availability of $17.8 \mathrm{~kg} \mathrm{DM} / \mathrm{cow} /$ day.

Table 2 shows the chemical composition of pastures, where there were no significant differences $(\mathrm{P}>0.05)$ for any of the variables between pastures or among periods. Mean CP content of herbage was $205.2 \mathrm{~g} 7 \mathrm{~kg}$ DM, 510.1.1 g/kg DM for NDF and 235.4 ADF, with a mean IVOMD of 744.2 representing and estimated mean ME content of $9.8 \mathrm{MJ} \mathrm{ME} / \mathrm{kg} \mathrm{DM}$, indicating good nutritional value in both pastures.

Table 1. Sward height and Net Herbage Accumulation (NHA).

\begin{tabular}{|l|l|c|c|c|c|c|}
\hline \multirow{2}{*}{ Variable } & \multirow{2}{*}{ Variety } & \multicolumn{4}{c|}{ Periods } & \multirow{2}{*}{ Mean } \\
\cline { 3 - 6 } & & I & II & III & IV & \\
\hline \multirow{2}{*}{ Sward height $(\mathrm{cm})$} & Ryegrass & 8.0 & 9.2 & 8.2 & 7.4 & 8.3 \\
\cline { 2 - 6 } & Tall Fescue & 5.7 & 6.1 & 6.8 & 9.1 & 6.9 \\
\hline $\begin{array}{l}\text { NHA per period }(\mathrm{kg} \\
\text { DM/ha/period) }\end{array}$ & Ryegrass & 609.9 & 795.5 & 405.5 & 344.3 & 559.1 \\
\cline { 2 - 7 } & Tall Fescue & 556.0 & 554.4 & 848.2 & 630.5 & 647.3 \\
\hline $\begin{array}{l}\text { NHA per day }(\mathrm{kg} \\
\text { DM/ha/día) }\end{array}$ & Ryegrass & 49.3 & 56.8 & 28.9 & 24.4 & 39.9 \\
\cline { 2 - 6 } & Tall Fescue & 39.7 & 39.6 & 60.5 & 45.0 & 46.2 \\
\hline
\end{tabular}

PI= Period I, PII= Period II, PIII= Period III, PIV= Period IV, NHA per period (kg DM/ha/period)

Table 2. Chemical composition, in vitro organic matter digestibility (IVOMD) and estimated metabolizable energy content (eME) of pastures.

\begin{tabular}{|c|c|c|c|c|c|c|c|c|c|}
\hline \multirow[t]{2}{*}{ Variable } & \multirow[t]{2}{*}{ Variety } & \multicolumn{4}{|c|}{ Periods } & \multirow{2}{*}{$\begin{array}{l}\text { Mean } \\
\text { TX }\end{array}$} & \multirow[t]{2}{*}{ SEMTx } & \multirow{2}{*}{ SEMExP } & \multirow{2}{*}{\begin{tabular}{|l|} 
P- \\
Value
\end{tabular}} \\
\hline & & I & II & III & IV & & & & \\
\hline \multirow{2}{*}{$\begin{array}{l}\mathrm{OM}(\mathrm{g} / \mathrm{kg} \\
\mathrm{DM})\end{array}$} & Ryegrass & 870.8 & 873.1 & 877.2 & 870.0 & 872.8 & \multirow[t]{2}{*}{0.94} & \multirow[t]{2}{*}{1.94} & \multirow{2}{*}{$\begin{array}{l}0.190 \\
N S\end{array}$} \\
\hline & Tall Fescue & 873.4 & 875.7 & 877.4 & 871.6 & 874.5 & & & \\
\hline \multirow{2}{*}{$\begin{array}{l}\mathrm{CP}(\mathrm{g} / \mathrm{kg} \\
\mathrm{DM})\end{array}$} & Ryegrass & 220.5 & 196.0 & 192.5 & 178.5 & 196.9 & \multirow[t]{2}{*}{3.06} & \multirow[t]{2}{*}{0.54} & \multirow{2}{*}{$\begin{array}{l}0.292 \\
N S\end{array}$} \\
\hline & Tall Fescue & 206.4 & 192.5 & 213.5 & 241.4 & 213.5 & & & \\
\hline \multirow{2}{*}{$\begin{array}{l}\text { NDF }(g / k g \\
D M)\end{array}$} & Ryegrass & 493.4 & 541.6 & 474.0 & 459.4 & 492.1 & \multirow[t]{2}{*}{10.42} & \multirow[t]{2}{*}{1.03} & \multirow{2}{*}{$\begin{array}{l}0.161 \\
N S\end{array}$} \\
\hline & Tall Fescue & 471.7 & 573.7 & 543.2 & 523.5 & 528.0 & & & \\
\hline \multirow{2}{*}{$\begin{array}{l}\mathrm{ADF}(\mathrm{g} / \mathrm{kg} \\
\mathrm{DM})\end{array}$} & Ryegrass & 236.1 & 236.4 & 258.7 & 238.9 & 242.4 & \multirow[t]{2}{*}{0.46} & \multirow[t]{2}{*}{0.58} & \multirow{2}{*}{$\begin{array}{l}0.449 \\
N S\end{array}$} \\
\hline & Tall Fescue & 174.5 & 246.4 & 241.1 & 251.3 & 228.3 & & & \\
\hline \multirow[t]{2}{*}{ IVOMD } & Ryegrass & 825.6 & 823.6 & 760.7 & 772.5 & 795.6 & \multirow[t]{2}{*}{6.35} & \multirow[t]{2}{*}{0.61} & \multirow{2}{*}{$\begin{array}{l}0.181 \\
N S\end{array}$} \\
\hline & Tall Fescue & 735.3 & 666.0 & 660.2 & 709.3 & 692.7 & & & \\
\hline \multirow{2}{*}{$\begin{array}{l}\text { eME } \\
\mathrm{MJ} / \mathrm{kg} \mathrm{DM}\end{array}$} & Ryegrass & 11.0 & 11.4 & 10.9 & 10.9 & 11.0 & \multirow[t]{2}{*}{8.7} & \multirow[t]{2}{*}{2.9} & \multirow{2}{*}{$\begin{array}{l}0.057 \\
N S\end{array}$} \\
\hline & Tall Fescue & 10.2 & 9.5 & 9.5 & 9.7 & 9.7 & & & \\
\hline
\end{tabular}

$\mathrm{OM}=$ Organic matter; $\mathrm{CP}=$ Crude proetin; $\mathrm{NDF}=$ Neutral detergent fibre; $\mathrm{ADF}=\mathrm{Acid}$ detergent fibre; $\mathrm{IVOMD}=$ In vitro organic matter digestibility. ME= Metabolizable energy; SEMTx= Standard Error of the Mean for pasture treatments (main plots); $\mathrm{SEMExP}=$ Standard Error of the Mean for experimental periods $($ split plot $) ;{ }^{\mathrm{NS}}=$ Not significant $(\mathrm{P}>0.05)$. 
Table 3 shows the chemical composition of supplements, both for the commercial compound concentrate as well as for the triticale hay. The chemical composition of the concentrate was as expected from the label. Triticale hay had a low CP content but had a good IVOMD given de medium content of $\mathrm{NDF}$ and ADF which yielded a good quality forage with an ME content of $10.4 \mathrm{MJ} \mathrm{ME} / \mathrm{kg} \mathrm{DM}$.

\section{Animal variables}

Table 4 shows results for animal variables. There were no significant differences $(\mathrm{P}>0.05)$ for animal variables due to pasture type, triticale hay complementation, or the interaction, except for pasture herbage dry matter intake $(\mathrm{P}<0.05)$. There was a trend $(\mathrm{P}<0.07)$ for higher milk yields when cows grazed the perennial ryegrass pasture.Herbage DMI in the treatments with hay complementation was $4.5 \mathrm{~kg}$ $\mathrm{DM} /$ cow/day, and $7.5 \mathrm{~kg} \mathrm{DM}$ pasture herbage/cow/day for treatments without triticale hay.

Table 3. Chemical composition of concéntrate commercial and of hay of triticale.

\begin{tabular}{|l|l|l|l|l|l|l|l|}
\hline $\begin{array}{l}\text { Chemical composition } \\
(\mathrm{g} / \mathrm{kg} \text { DM })\end{array}$ & DM & OM & CP & NDF & ADF & IVOMD & $\begin{array}{l}\text { eME } \\
\text { MJ/kg DM }\end{array}$ \\
\hline $\begin{array}{l}\text { Concentrate } \\
\text { commercial }\end{array}$ & 929.4 & 955.6 & 185.3 & 282.4 & 141.1 & 926.8 & 12.9 \\
\hline Hay of Triticale & 920.4 & 941.1 & 66.4 & 560.1 & 283.5 & 713.3 & 10.4 \\
\hline
\end{tabular}

$\mathrm{DM}=$ Dry matter; $\mathrm{OM}=$ Organic matter; $\mathrm{CP}=$ Crude proetin; $\mathrm{NDF}=$ Neutral detergent fibre; $\mathrm{ADF}=$ Acid detergent fibre; IVOMD= In vitro organic matter digestibility. $\mathrm{ME}=$ Metabolizable energy.

Table 4. Animal variables

\begin{tabular}{|c|c|c|c|c|c|c|}
\hline \multirow{2}{*}{ Variables } & \multicolumn{3}{|c|}{ Treatment } & & \multirow{2}{*}{ SEM } & \multirow{2}{*}{ P-Value } \\
\hline & TFH & $\mathrm{RGH}$ & RGNH & TFNH & & \\
\hline MY (kg/vaca/día) & 14.9 & 15.9 & 16.1 & 14.9 & 0.26 & $0.072^{\mathrm{NS}}$ \\
\hline Milk fat (g/kg) & 38.3 & 37.2 & 38.0 & 38.5 & 0.022 & $0.143^{\mathrm{NS}}$ \\
\hline Protein $(\mathrm{g} / \mathrm{kg})$ & 31.4 & 31.2 & 31.4 & 31.5 & 0.008 & $0.471^{\mathrm{NS}}$ \\
\hline Lactose $(\mathrm{g} / \mathrm{kg})$ & 45.4 & 45.3 & 44.8 & 45.6 & 0.019 & $0.265^{\mathrm{NS}}$ \\
\hline MUN (mg/dL) & 11.5 & 11.9 & 10.3 & 14.2 & 0.36 & $0.185^{\mathrm{NS}}$ \\
\hline LW (kg) & 537.3 & 531.3 & 531.3 & 534.0 & 3.19 & $0.520^{\mathrm{NS}}$ \\
\hline BCS (1-5) & 2.0 & 2.0 & 2.0 & 2.0 & 0.00 & \\
\hline $\begin{array}{l}\text { Herbage DMI (kg } \\
\text { DM/cow/day }\end{array}$ & 4.6 & 4.4 & 7.4 & 7.7 & 0.12 & $0.367 *$ \\
\hline
\end{tabular}

$\mathrm{MY}=$ Milk yield , MUN= Milk urea nitrogen; $\mathrm{LW}=$ Live weight $\mathrm{BCS}=$ Body condition score

$\mathrm{SEM}=$ Standard Error of the Mean; TFH= Tall fescue + triticale hay; RGH= Perennial ryegrass + triticale hay; $\mathrm{RGNH}=$ Pereennial ryegrass no hay; TFNH= Tall fescue no hay. NS $(\mathrm{P}>0.05) . *(\mathrm{P}<0.05)$.

\section{Discussion}

Pasture variables

Minimum sward height, measured with a ruler, established to enable adequate intake at set stocked grazing is between 5 and $8 \mathrm{~cm}$ (Mayne et al., 2000), so that sward height in this experiment was not limiting grazing, with mean grass metre sward heights of $8.4 \mathrm{~cm}$ for the perennial ryegrass pasture and $6.9 \mathrm{~cm}$ for the tall fescue pasture, although in NHA, the tall fescue pasture had $16 \%$ higher herbage growth.

Crude protein content and dry matter digestibility, the latter determined to a large extent by the NDF and ADF contents, are two characteristics of forage quality and nutritive value. The chemical composition of herbage in these variables indicates high quality of herbage from both pastures.

The mean CP content of both pastures was $203.7 \mathrm{~g} / \mathrm{kg}$ DM, was similar to reports by Heredia-Nava et al. (2007) for perennial ryegrass pastures associated with white clover, and higher to reports by Plata-Reyes et al. (2018) for CP content of perennial ryegrass and tall fescue pastures, similar to those in the study herein reported.

Triticale hay showed a low CP content at $66.4 \mathrm{~g} / \mathrm{kg}$ DM, much lower than $185 \mathrm{~g} \mathrm{CP} / \mathrm{kg} \mathrm{DM}$ reported by Santana et al. (2019) for a large-scale dairy operation. Nonetheless, the low CP content of triticale hay did not have a detrimental effect as it was compensated by the CP content of pasture herbage and the concentrate.

NDF and ADF content in pasture herbage was within reports in the literature (Plata-Reyes et al., 2018) that resulted in high IVOMD and high ME content. Herbage from both pastures had a high estimated ME content, although there was a trend $(\mathrm{P}<0.06)$ for a higher ME content in the perennial 
ryegrass pasture than in the tall fescue pasture highlighting the higher nutritive value of perennial ryegrass pastures

NDF and ADF content of triticale hay was slightly above values for the herbages, although lower than reported for triticale silage (González-Alcántara et al., 2020). However, IVOMD was the same for both triticale forages, silage reported by Gonzalez-Alcántara et al. (2020) and triticale hay herein reported. Estimated ME content of triticale hay was high and even higher than the tall fescue pasture herbage (Tables 2 and 3).

\section{Animal variables}

Mean milk yield was $15.5 \mathrm{~kg} / \mathrm{cow} /$ day, similar to reports by Celis-Alvarez et al. (2016) who reported $15.6 \mathrm{~kg} / \mathrm{cow} /$ day, López-González et al. (2017) who reported $15.7 \mathrm{~kg} / \mathrm{cow} /$ day, and Plata-Reyes et al. (2018) with mean yields of $14.9 \mathrm{~kg} / \mathrm{cow} /$ day. Observed yields were however higher than mean milk yields of $13.2 \mathrm{~kg} / \mathrm{cow} /$ day reported by Martínez-García et al. (2015), and from González-Alcántara et al. (2020) who reported mean milk yields of $12.3 \mathrm{~kg} / \mathrm{cow} /$ day from cows complemented with triticale silage; although lower than reports by Heredia-Nava et al. (2007), Anaya-Ortega et al. (2009), and Albarrán et al. (2012) who reported milk yields over $18 \mathrm{~kg}$ milk/cow/day. All these reports were from work in similar small-scale dairy farms.

Milk fat, protein and lactose content were very similar within treatments, with mean values of $30.7 \mathrm{~g} / \mathrm{kg}$ for milk fat, $31.3 \mathrm{~g} / \mathrm{kg}$ for protein, and $45.2 \mathrm{~g} / \mathrm{kg}$ for lactose content. These values are within Mexican standards for raw milk composition. Milk urea nitrogen (MUN) had a mean value of 12.0 $\mathrm{mg} / \mathrm{dL}$, ranging from 11.3 to $14.2 \mathrm{mg} / \mathrm{dL}$, within the accepted range for dairy cows (Powell et al., 2011).

\section{Conclusions}

Although complementing cows with $3.0 \mathrm{~kg}$ DM of triticale hay/cow/day did not increased milk yields, milk composition or other animal variables, complementing the diet of grazing dairy cows in small-scale dairy farms with triticale hay during the dry season reduces pasture deterioration due to high grazing pressure and decreased herbage growth.

\section{Acknowledgments}

Authors express gratitude to the collaborating farmer and his family who participated in this study, whose privacy is respected by not disclosing their names. This work was undertaken thanks to funding by the Mexican National Council for Science and Technology (Consejo Nacional de Ciencia y Tecnología-CONACYT) through grant 129449 CB-2009, and for the postgraduate grant for María Nayeli Marín-Santana. Our thanks also to Ms. Maria de Lourdes Maya-Salazar and Ms. Laura Edith ContrerasMartínez for their assistance in laboratory analyses.

\section{References}

1) AFRC - Animal and Food Research Council, 1993. Energy and protein requirements of ruminants.CAB International, Wallingford, UK.

2) Albarrán B, García A, Espinoza A, Espinosa E, Arriaga CM, 2012.Maize silage in the dry season for grazing dairy cows in small-scale production systems in Mexico's highlands. Indian Journal of Animal Research 46(4): 317-324.

3) Anaya-Ortega JP, Garduño-Castro G, Espinoza-Ortega A, Rojo-Rubio R, Arriaga-Jordán CM, 2009. Silage from maize (Zea mays), annual ryegrass (Lolium multiflorum) or their mixture in the dry season feeding of grazing dairy cows in small-scale dairy production systems in the highlands of Mexico. Tropical Animal Health and Production 41: 607-616.

4) Celis-Alvarez MD, López-González F, Martínez-García CG, Estrada-Flores JG, Arriaga-Jordán CM, 2016.Oat and ryegrass silage for small-scale dairy systems in the highlands of central Mexico. Tropical Animal Health and Production 48: 1129-1134. DOI 10.1007/s11250-0161063-0.

5) Chaney AL, Marbach EP, 1962. Modified reagents for determination of urea and ammonia. ClinicalChemistry 8 : 130-132.

6) Conroy C, 2005. Participatory livestock research: a guide. ITDG Publishing, Bourton-on-Dunsmore, UK.

7) Espinoza-Ortega A, Espinosa-Ayala E, Bastida-López J, Castañeda-Martínez T, Arriaga-Jordán CM, 2007.Smallscale dairy farming in the highlands of central Mexico, technical, economic and social aspects and their impact on poverty. Experimental Agriculture 43: 241-256.

8) Fadul-Pacheco L, Wattiaux MA, Espinoza-Ortega A, Sánchez-Vera E, Arriaga-Jordán CM, 2013.Evaluation of sustainability of smallholder dairy production systems in the highlands of Mexico during the rainy season. Agroecology and Sustainable Food Systems37: 882-901.

9) Feroze SM, Sing R, Sirhi S, 2017. Fodder and labour for augmenting milk production in hills: A case study of Meghalaya. Indian Journal of Dairy Science 70: 611-615.

10) Gómez-Miranda A, Estrada-Flores JG, Morales-Almaraz E, López-González F, Flores-Calvete G, Arriaga-Jordán CM, 2020.Barley or black oat silages in feeding strategies for small-scale dairy systems in the highlands of Mexico. Canadian Journal of Animal Science 100: 221-227. http://dx.doi.org/10.1139/cjas-2018-0237.

11) González-Alcántara FJ, Estrada-Flores JG, Morales-Almaraz E, López-González F, Gómez-Miranda A, VegaGarcía JI, Arriaga-Jordán CM, 2020.Whole-crop triticale silage for dairy cows grazing perennial ryegrass 
(Lolium perenne) or tall fescue (Lolium arundinaceum) pastures in small-scale dairy systems during the dry season in the highlands of Mexico. Tropical Animal Health and Production 52: 1903-1910. https://doi.org/10.1007/s11250-020-02206-9.

12) Granados-Rivera LD, Hernández-Mendo O, González-Muñoz SS, Burgueño-Ferreira JA, Mendoza-Martínez GD, Arriaga-Jordán CM, 2017.Effect of palmitic acid on the mitigation of milk fat depression syndrome caused by trans-10, cis-12-conjugated linoleic acid in grazing dairy cows. Archives of Animal Nutrition 71: 428--440. https://doi.org/10.1080/1745039X.2017.1379165

13) Haselmann A, Wenter M, Fuerst-Waltl B, Zollistsch W, Zebeli Q, Knaus W, 2020. Comparing the effects of silage and hay from similar parent grass forages on organic dairy cows' feeding behavior, feed intake and performance. Animal Feed Science and Technology 267: 114560.

14) Heredia-Nava D, Espinoza-Ortega A, González- Esquivel CE, Arriaga-Jordán CM, 2007. Feeding strategies for small-scale dairy systems based on perennial (Lolium perenne) or annual (Lolium multiflorum) ryegrass in the central highlands of Mexico. Tropical Animal Health and Production 39: 179-188.

15) Kaps M, Lamberson W, 2004. Biostatistics for Animal Science.Cromwell Press, Trowbridge, UK. pp $294-312$.

16) López-González F, Rosas-Davila M, Celis-Alvarez MD, Morales-Almaraz E, Domínguez-Vara IA, ArriagaJordan CM, 2017.Milk production under grazing of different pasture grasses in small-scale dairy systems in the highlands of central Mexico. Journal of Livestock Science 8: 92-97.

17) Martínez-García CG, Rayas-Amor A, Anaya-Ortega JP, Martínez-Castañeda F E, Espinoza-Ortega A, ProsperoBernal F, Arriaga-Jordan CM, 2015.Performance of small-scale dairy farms in the highlands of central Mexico during the dry season under traditional feeding strategies. Tropical Animal Health and Production 47: 331-337.

18) Mc Dermott JJ, Stall SJ, Freeman HA, Van de Steeg JA, 2010.Sustaining intensification of smallholder livestock systems in the tropics. Livestock Science 130: 95-109.

19) Mayne CS, Wright I, and Fisher GEJ, 2000. Grassland management under grazing and animal response. In: Hopkins A. et al. (ed) Grass: Its production and utilization. Chapter 10. Blackwell Science,Oxford, UK.pp. 247-291

20) Miguel MF, Ribeiro-Filho HMN, de Andrade EA, Moraes Genro MT, Delagarde R, 2014.Pasture intake and milk production of dairy cows grazing annual ryegrass with or without corn silage supplementation. Animal Production Science54: 1810-1816.

21) Plata-Reyes DA, Morales-Almaraz E, Martínez-García CG, Flores-Calvete G, López-González F, PrósperoBernal F, Valdez-Ruiz CL, Zamora-Juárez YG, Arriaga-Jordán CM, 2018.Milk production and fatty acid profile of dairy cows grazing four grass species pastures during the rainy season in small-scale dairy systems in the highlands of Mexico. Tropical Animal Health and Production 50: 1797-1805

22) Powell M, Wattiaux A, Broderick GA, 2011. Short communication: evaluation of milk urea nitrogen as a management tool to reduce ammonia emissions from dairy farms. Journal of Dairy Science 94: 4690-4695

23) Prospero-Bernal F, Martinez-García CG, Olea-Pérez R, López-González F, Arriaga-Jordán CM, 2017. Intensive grazing and maize silage to enhance the sustainability of small-scale dairy systems in the highlands of Mexico. Tropical Animal Health and Production 49: 1537-1544.

24) Riveros E, Argamentaría A, 1987. Métodos enzimáticos de predicción de la digestibilidad in vivo de la materia orgánica de forrajes. Avances en Producción Animal 12: 59-75.

25) Sainz-Ramírez A, Estrada-Flores JG, Morales-Almaraz E, Flores-Calvete G, López-González F, Arriaga-Jordán CM, 2021. Effect of the inclusion of sunflower silage for cows in small-scale dairy systems in the highlands of Mexico. Journal of Livestock Science 12: 95-102; DOI: 10.33259/JLivestSci.2021.95-102.

26) Sánchez-Gutiérrez RA, Gutiérrez-Bañuelos H, 2015.Forage characteristics of triticale varieties under drought. RevistaMexicanade Ciencias Agrícolas 6: 645-650.

27) Santana OI, Olmos-Colmenero JJ, Wattiaux MA, 2019.Replacing alfalfa hay with triticale hay has minimal effects on lactation performance and nitrogen utilization of dairy cows in a semi-arid region of Mexico. Journal of Dairy Science 102: 8546-8558

28) Serrapica F, Uzun P, Masucci F, Napolitano F, Braghieri A, Genovese A, Sacchi R, Romano R, Barone CMA, Di Francia A, 2020. Hay or silage? How the forage preservation method changes the volatile compounds and sensory properties of Caciocavallo cheese. Journal of Dairy Science 103:1391-1403. https://doi.org/10.3168/jds.2019-17155

29) Suttie JM, 2000.Hay and Straw Conservation - For Small-Scale Farming and Pastoral Conditions. FAO Plant Production and Protection Series No. 29. Food and Agriculture Organization of the United Nations (FAO), Rome.

30) Valle-Aguilar M, Sainz-Ramírez A, López-González F, Arriaga-Jordán CM, 2020.Prevalence subclinical mastitis in small-scale dairy farms under grazing or in total confinement in the central highlands of Mexico. Indian Journal of Dairy Science 73: 73-76. 